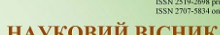

$\longrightarrow$

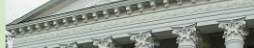

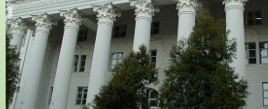

СЕРЯ "СЛЬСБКОГОСПОДАРСКК НАУКІ

Том 23 № 95 2021
Науковий вісник Дьвівського національного університету ветеринарної медицини та біотехнологій імені С.3. Гжицького. Серія: Сільськогосподарські науки

\section{Scientific Messenger of Lviv National University} of Veterinary Medicine and Biotechnologies. Series: Agricultural sciences

doi: 10.32718/nvlvet-a9519

ISSN 2707-5834 online

https://nvlvet.com.ua/index.php/agriculture

UDC 636.52/.58.033.087.72

\title{
Modeling effect of selenium on broiler chickens' body
}

O. I. Sobolev ${ }^{1}$, B. V. Gutyj ${ }^{2}$, Y. V. Zasukha ${ }^{1}$, P. M. Karkach ${ }^{1}$, V. F. Fesenko ${ }^{1}$, V. V. Bilkevych ${ }^{1}$, P. I. Kuzmenko ${ }^{1}$, Y. O. Mashkin ${ }^{1}$, S. V. Sobolieva ${ }^{1}$

${ }^{1}$ Bila Tserkva National Agrarian University, Bila Tserkva, Ukraine

${ }^{2}$ Stepan Gzhytskyi National University of Veterinary Medicine and Biotechnologies Lviv, Ukraine

Article info

Received 16.06.2021

Received in revised form 19.07 .2021

Accepted 20.07.2021

Bila Tserkva National Agrarian University, 8/1, Soborna Sq. Bila Tserkva, 09117, Ukraine. Tel.: + 38-096-443-91-50 E-mail: sobolev_a_i@ukr.net

Stepan Gzhytskyi National University of Veterinary Medicine and Biotechnologies Lviv,

Pekarska Str., 50, Lviv,

79010, Ukraine.

Tel.: +38-068-136-20-54

E-mail: bvh@ukr.net
Sobolev, O. I., Gutyj, B. V., Zasukha, Y. V., Karkach, P. M., Fesenko, V. F., Bilkevych, V. V., Kuzmenko, P. I., Mashkin, Y. O., \& Sobolieva, S. V. (2021). Modeling effect of selenium on broiler chickens' body. Scientific Messenger of Lviv National University of Veterinary Medicine and Biotechnologies. Series: Agricultural sciences, 23(95), 128-135. doi: 10.32718/nvlvet-a9519

In recent years, based on new scientific data, many countries worldwide have been revising the existing standards for introducing trace elements in mixed feed for highly productive broiler chicken crosses. This also applies to selenium, which is recognized as an indispensable biotic ultramicroelement with a wide range of biological action according to modern classification. However, some aspects of the selenium effects on poultry have not been elucidated yet. We have conducted comprehensive research to deepen and expand modern ideas about the biological role of selenium, its impact on the interior and productive qualities of broiler chickens in the post-embryonic period of ontogenesis. One of the tasks was to study the causal relationship between the level of selenium consumption by broiler chickens and the studied indicators. The research was conducted on broiler chickens of the Cobb 500 cross. During the rearing period, the feeding of broiler chickens of all groups was carried out with dry full-fledged mixed feeds following the existing norms. The poultry of the first control group did not receive selenium supplementation. The poultry of the second experimental group was additionally injected with Selenium at the rate of $0.2 \mathrm{mg} / \mathrm{kg}$, the third of 0.3 , and the fourth of $0.4 \mathrm{mg} / \mathrm{kg}$. When conducting a correlation analysis of the obtained experimental data, it was found that there are different levels and directions of relationship between internal and economically valuable features included in the study, which may vary depending on the selenium content in mixed feed for broiler chickens. A scheme of modeling the effect of selenium on broiler chickens' bodies is proposed.

Key words: selenium, feed, broiler chickens, productive qualities, correlations.

\section{Моделюючий вплив Селену на організм курчат-бройлерів}

\author{
О. І. Соболєв ${ }^{1}$, Б. В. Гутий ${ }^{2}$, Ю. В. Засуха ${ }^{1}$, П. М. Каркач ${ }^{1}$, В. Ф. Фесенко ${ }^{1}$, В. В. Бількевич ${ }^{1}$, \\ П. І. Кузьменко ${ }^{1}$ Ю. О. Машкін ${ }^{1}$, С. В. Соболєва
}

${ }^{1}$ Білоиерківський національний аграрний університет, м. Біла Церква, Украӥна

${ }^{2}$ Львівський національний університет ветеринарної медицини та біотехнологій імені С. 3. Гжиџького, м. Львів, Україна

Останніми роками у багатьох краӥнах світу переглядаються, із урахуванням нових наукових даних уже існуючі норми введення мікроелементів у комбікорми для високопродуктивних кросів курчат-бройлерів. Це стосується $і$ Селену, який, згідно з сучасною класифікаиією, визнаний незамінним біотичним ультрамікроелементом з иироким спектром біологічної дії. Проте деякі аспекти впливу Селену на організм птиці ще остаточно не з'ясовані. 3 метою поглиблення і розширення сучасних уявлень про біологічну роль Селену, його вплив на інтер'єр та продуктивні якості курчат-бройлерів у постембріональний період онтогенезу нами були проведені комплексні наукові дослідження. Одним із завдань було вивчення причинно-наслідкового взаємозв'язку між рівнем споживання курчатами-бройлерами Селену та досліджуваними показниками. Дослідження проводилися на курчатах-бройлерах кросу СОВВ 500. Годівля курчат-бройлерів усіх груп упродовж періоду вирошування здійснювалася сухими повнораиіонними комбікормами відповідно до існуючих норм. Птиця периої контрольної групи добавку селену не одержували. Птиці другої дослідної групи у 
комбікорми додатково вводили Селен із розрахунку 0,2 мг/кг, третьої-0,3 та четвертої-0,4 мг/кг. При проведенні кореляційного аналізу одержаних експериментальних даних встановлено, щз між інтер 'єрними та господарсько корисними ознаками, щзо входили в аналіз, мають місие різні рівні й напрями взаємозв'язку, які можуть змінюватися залежно від вмісту Селену в комбікормах для курчат-бройлерів. Запропоновано схему моделюючого впливу селену на організм курчат-бройлерів.

Ключові слова: Селен, корми, курчата-бройлери, продуктивні якості, кореляційні зв 'язки.

Вступ

Значну роль у гарантуванні національної продовольчої безпеки та експортного потенціалу України відіграє галузь птахівництва. Вона не тільки забезпечує споживачів цінними продуктами харчування, а й суттєво впливає на економічний потенціал країни. У зв'язку з цим подальший розвиток даної галузі сільського господарства $є$ одним із пріоритетних завдань аграрної політики держави.

Сьогодні питання, пов'язані з підвищенням продуктивності сільськогосподарської птиці та одержанням продукції високої якості, розробляються у різних аспектах. Серед численних елементів технологічного процесу, що забезпечують максимальний прояв генетичного потенціалу сільськогосподарської птиці, іiі високу продуктивність та життєздатність, важлива роль відводиться повноцінній годівлі. Сучасна система нормованої годівлі сільськогосподарської птиці передбачає повне задоволення іiі індивідуальної потреби в енергії, поживних і біологічно активних речовинах, у тому числі й мікроелементах (Provatorov \& Provatorova, 2015).

Загальновідомо, що мікроелементи не можуть бути синтезовані в організмі чи замінені іншими речовинами, тому основним джерелом надходження їх в організм сільськогосподарської птиці $є$ корми (Górniak et al., 2018; Nys et al., 2018). Вітчизняний та зарубіжний досвід переконливо доводять, що введення в комбікорми для сільськогосподарської птиці мікроелементів в оптимальних кількостях і співвідношеннях дозволяє не тільки підвищити її продуктивність і життєздатність, а й поліпшити конверсію корму та якість продукції. Незважаючи на те, що існує значна кількість наукових напрацювань щодо проблеми мінерального живлення сільськогосподарської птиці, перелік мікроелементів, які використовуються у ऑii раціоні, явно недостатній. Останніми роками у багатьох країнах світу переглядаються, із урахуванням нових наукових даних, уже існуючі норми введення мікроелементів у комбікорми для високопродуктивних кросів і порід сільськогосподарської птиці. Це стосується і Селену, який, згідно з сучасною класифікацією, визнаний незамінним біотичним ультрамікроелементом (Surai et al., 2018).

Аналіз результатів наукових досліджень учених 3 різних країн світу показав, що Селен $є$ мікроелементом 3 широким спектром біологічної дії (Sobolev et al., 2018). За результатами чисельних наукових досліджень, проведених на різних видах сільськогосподарських тварин і птиці, встановлено, що Селен володіє імуностимулюючими (Huang et al., 2012), антивірусними (Shojadoost et al., 2019), антиоксидантними (Zoidis et al., 2018), антитоксичними (Mughal et al., 2017), антиканцерогенними (Kuršvietienė et al., 2020), адаптогенними (Shakeri et al., 2020), радіопротектор- ними (Graupner et al., 2016) та іншими властивостями. Проте деякі аспекти впливу Селену на організм птиці або остаточно ще не 3'ясовані, або залишилися поза увагою вчених, або не знайшли свого відображення у наукових статтях.

Вже перші спроби використання Селену як мінеральної добавки у годівлі сільськогосподарської птиці дозволили одержати результати, які доводять безумовну необхідність визначення оптимальних норм уведення Селену в комбікорми для сільськогосподарської птиці, у тому числі й для курчат-бройлерів (Sobolev et al., 2021).

Норми введення Селену в комбікорми для курчатбройлерів, що рекомендовані в різних країнах світу, мають певні відмінності та коливаються від 0,1 до 0,5 мг/кг корму. Причиною розбіжностей є, напевно, те, що наукові дослідження проводилися на різних кросах птиці, на фоні різних раціонів, у різних умовах і за використання різних селеновмісних сполук.

Сьогодні російські вчені вважають, що для досягнення високої продуктивності в комбікорми для курчат-бройлерів достатньо вводити Селен у дозі 0,2 мг/кг (Fisinin, 2005). Цієї ж думки дотримуються i вчені з американської компанії Hubbard (Navidshad et al., 2019).

Науковці фірми “Coob” вважають, що норма добавок Селену до комбікормів для курчат-бройлерів має становити 0,35 мг/кг (Cobb 500, 2018). Інша англійська птахівницька фірма “Aviagen” рекомендує для курчат-бройлерів вводити в комбікорми селен у кількості 0,3 мг/кг (Ross Broiler, 2019).

Згідно з рекомендаціями бразильських учених, норма введення Селену в комбікорми для курчатбройлерів у період росту 1-7 днів має становити 0,375 мг/кг; 8-21 день - 0,33; 22-33 дні - 0,30; 34-42 дні - 0,225 та 43-49 днів - 0,195 мг/кг (Rostagno et al., 2011).

Згідно 3 рекомендаціями білоруських учених, рівень Селену в повнораціонних комбікормах для курчат-бройлерів має становити 0,5 мг/кг (Ponomarenko, 2007).

Водночас канадські вчені стверджують, що концентрація Селену в повнораціонних комбікормах для курчат-бройлерів не повинна бути більше ніж 0,3 мг/кг (CFIA, 2018).

Українські вчені порівняно недавно стали рекомендувати комбікорми для різних видів сільськогосподарської птиці, у тому числі й курчат-бройлерів, збагачувати Селеном із розрахунку 0,1 мг/кг (Bratishko et al., 2013). Проте ця доза відповідає лише мінімальній фізіологічній потребі птиці у цьому мікроелементі.

Як видно з викладеного вище, рекомендовані зарубіжними та вітчизняними вченими норми введення Селену в комбікорми для курчат-бройлерів, суперечливі i, на нашу думку, їх слід оцінювати як орієнтовні, такі, що потребують подальшого уточнення залежно 
від біологічних і регіональних особливостей годівлі птиці.

Крім того, аналіз літературних джерел показав, що експериментальні дані щодо впливу різних доз і сполук цього мікроелемента на продуктивність курчатбройлерів і якість продукції також досить суперечливі та не завжди підкріплені викладками теоретичного, статистичного й економічного характеру. Все це підтверджує необхідність проведення комплексних досліджень щодо розробки, теоретичного та експериментального обгрунтування оптимальної норми введення Селену в комбікорми для курчат-бройлерів з метою підвищення їхньої продуктивності, ефективності використання кормів і поліпшення якості продукції.

Сучасна зоотехнічна наука використовує багато методів оцінки впливу різних факторів на рівень продуктивності тварин і птиці, але особливе місце серед них займає кореляційний аналіз.

Завдання кореляційного аналізу полягають у встановлені сили (або тісноти) зв'язку між окремими ознаками, у визначені невідомих причинних зв'язків і в оцінці факторів, що мають найбільший вплив на результативну ознаку.

Відсутність такого аналізу може знизити ефективність годівлі птиці, оскільки кожен показник продуктивності - це складна результативна ознака, яка пов'язана з іншими, іноді й небажаними кореляціями.

Вивчення кореляційних зв'язків між кількісними та якісними ознаками дозволяє визначити, за рахунок яких факторів можна більш ефективно підвищити продуктивність сільськогосподарської птиці.

У зв’язку з цим метою наших досліджень було вивчення причинно-наслідкового взаємозв'язку між рівнем споживання курчатами-бройлерами Селену та досліджуваними показниками.

\section{Матеріал і методи досліджень}

Дослідження проводилися на курчатах-бройлерах кросу СОВВ 500. Для проведення науковогосподарського досліду формували групи із добового молодняку за принципом аналогів 3 урахуванням живої маси, походження та фізіологічного стану (рухливість, стан пуповини та оперення). Тривалість досліду відповідала періоду вирощування курчатбройлерів на м'ясо і становила 42 дні.

Годівля курчат $з$ добового до 42-денного віку здійснювалася сухими повнораціонними комбікормами, що збалансовані за основними поживними та біологічно активними речовинами, відповідно до існуючих норм. Птиця першої контрольної групи добавку Селену в комбікорми не одержувала. Птиці дослідних груп у комбікорми додатково вводили різну кількість Селену згідно зі схемою досліду (табл. 1).

Як джерело Селену використовували селеніт натрію $\left(\mathrm{Na}_{2} \mathrm{SeO}_{3}\right)$ коефіцієнтом перерахунку елемента в сіль 2,20 .

\section{Таблиця 1}

Схема науково-господарського досліду

\begin{tabular}{lcc}
\hline \multicolumn{1}{c}{ Група } & $\begin{array}{c}\text { Кількість птиці } \\
\text { у групі, гол. }\end{array}$ & $\begin{array}{c}\text { Добавка в комбікорми } \\
\text { селену, мг/кг }\end{array}$ \\
\hline 1 контрольна & 100 & $\begin{array}{c}\text { Основний раціон } \\
\text { (комбікорм) }- \text { OP }\end{array}$ \\
2 дослідна & 100 & OР $+0,2$ \\
3 дослідна & 100 & OP $+0,3$ \\
4 дослідна & 100 & OP $+0,4$ \\
\hline
\end{tabular}

Під час проведення наукового дослідження були використані методи, які дозволили виявити закономірні зв'язки між досліджуваними явищами та процесами, зокрема зоотехнічні (показники росту птиці, іiі життєздатність), фізіологічні (перетравність поживних речовин, баланс Азоту і Селену), патологоанатомічні (забійні та м'ясні якості, розвиток шлунково-кишкового тракту), хімічні (вміст сухої речовини, протеїну, жиру, золи та Селену в біологічних об'єктах), токсико-біологічні (біологічна цінність м'яса), гематологічні (вміст еритроцитів, лейкоцитів, гемоглобіну, загального білка, імуноглобулінів, глутатіону) та статистичні (математична обробка результатів досліджень).

У ході експериментальних досліджень враховували такі показники:

- живу масу птиці - індивідуальним зважуванням на початку та в кінці періоду вирощування;

- збереженість птиці - щоденно зі встановленням причин вибуття.

3 метою вивчення впливу добавок різних доз селену в комбікорми на перетравність поживних речовин, баланс Азоту та Селену в організмі курчат-бройлерів на фоні науково-господарського досліду був проведений фізіологічний дослід відповідно до загальноприйнятої методики (Maslieva, 1967).

Кількість перетравних поживних речовин, баланс Азоту та Селену визначали за різницею між надходженням поживних і мінеральних речовин 3 кормом та виділенням їх з послідом та 3 калом. При визначенні перетравності сирого протеїну, відділення азотистих речовин калу від сечової кислоти та ії солей здійснювали хімічним методом, який запропонований М. І. Д'яковим.

По закінченні періоду вирощування, у 42-денному віці, було проведено контрольний забій курчатбройлерів. Після контрольного забою курчатбройлерів проводили повне анатомічне розбирання та обвалення їх тушок. Під час анатомічного розбирання тушок курчат-бройлерів здійснювали відбір середніх проб м'язової тканини (м'язів стегна, гомілки та грудей) для проведення хімічного аналізу.

Хімічний аналіз комбікормів, посліду та м'яса проводили такими методами:

- масова частка загальної вологості - шляхом висушування наважки до постійної маси у сушильній шафі (DSTU ISO 6496:2005, 2006; DSTU ISO 1442:2005, 2008);

- масова частка Азоту та сирого протеїну - за K'єльдалем (DSTU ISO 937:2005, 2007; DSTU ISO 5983-1:2014, 2015); 
- масова частка жиру - екстрагуванням етиловим спиртом в апараті Сокслета (DSTU ISO 6492:2003, 2005; DSTU ISO 1443:2005, 2008);

- масова частка клітковина - методом проміжного фільтрування (DSTU ISO 6865:2004, 2006);

- масова частка зола - шляхом озолення наважки у муфельній печі (DSTU ISO 5984:2004, 2006; DSTU ISO 936:2008, 2008);

- вміст Селену - методом полуменевої атомної абсорбції на спектрофотометрі “Сатурн - 3 П1” з використанням повітряно-ацетиленового полум'я та попередньою вологою мінералізацією зразків (Holak, 1980; Ermachenko, 1997);

Вміст безазотистих екстрактивних речовин (\%) у комбікормах і посліді визначали розрахунковим шляхом - за різницею між 100 та сумою процентів всіх інших речовин корму або посліду.

Харчову цінність (Х) м'яса курчат-бройлерів визначали за його хімічним складом і розраховували за формулою:

$$
\mathrm{X}=[\mathrm{C}-(Ж+3)] \times 4,0+(Ж \times 9,0),
$$

де $\mathrm{C}$ - вміст сухої речовини в м'ясі, \%; Ж - вміст жиру в м'ясі, \%; 3 - вміст золи в м'ясі, \%.

Відносну біологічну цінність м'яса курчатбройлерів визначали мікрометодом 3 використанням тест-організму інфузорії Тетрахімена піриформіс, штам $\mathrm{WH}_{14}$ (Mikitjuk et al., 2004).

У кінці періоду вирощування були відібрані проби крові у піддослідної птиці. Кров у курчат-бройлерів отримували до ранкової годівлі з підкрилової вени.

При дослідженні крові використовували такі методи:

- форменні елементи крові (еритроцити та лейко- цити) - меланжерним методом;

- гемоглобін - геміглобінціанідним методом;

- загальний білок у сироватці крові - рефрактометричним методом;

- загальну кількість імуноглобулінів у сироватці крові - фотоелектроколориметричним методом (Levchenko et al., 2004);

- загальний глутатіон та його форми (відновлений та окиснений) - йодометричним методом (Ejdrygevych \& Raevskaja, 1966).

При математичному опрацюванні результатів досліджень використовували комп'ютерні програми статистичної обробки Microsoft Excel. Різницю між показниками оцінювали за критерієм Стьюдента і вважали вірогідною при значеннях: ${ }^{*}-\mathrm{P}<0,05 ;^{* *}-\mathrm{P}<0,01$, *** $-\mathrm{P}<0,001$.

\section{Результати та їх обговорення}

На початковому етапі експериментальних досліджень ми поставили за мету визначити фактичний вміст Селену в комбікормах для курчат-бройлерів. Нашими дослідженнями встановлено, що у комбікормах для курчат-бройлерів середній вміст Селену становить 0,088 мг/кг, що вважається недостатніми навіть для задоволення мінімальної фізіологічної потреби (0,1 мг/кг) даного виду сільськогосподарської птиці у цьому мікроелементі (табл. 2). Звідси виникає нагальна необхідність у збагаченні комбікормів Селеном $з$ метою усунення його дефіциту в раціонах курчат-бройлерів.

Таблиця 2

Споживання курчатами-бройлерами Селену з кормом

\begin{tabular}{lcccc}
\hline \multicolumn{1}{c}{ Показник } & \multicolumn{3}{c}{ Група } \\
\cline { 2 - 5 } & 1 контрольна & 2 дослідна & 3 дослідна & 4 дослідна \\
\hline Вміст Селену в комбікормах, мг/кг & 0,088 & 0,288 & 0,388 & 0,488 \\
Споживання Селену за період вирощування (42 дні), мг/гол. & 0,255 & 0,831 & 1,130 & 1,412 \\
Споживання Селену за добу, мг/гол. & 0,006 & 0,020 & 0,027 & 0,034 \\
\hline
\end{tabular}

Введення додаткової кількості Селену до складу комбікормів для курчат-бройлерів згідно зі схемою досліду сприяло підвищенню рівня його споживання птицею дослідних груп. Так, середньодобове споживання Селену з кормом курчатами-бройлерами другої дослідної групи було вищим на 0,014 мг/гол, третьоїна 0,021 та четвертої - на 0,028 мг/кг порівняно 3 молодняком контрольної групи, де аналогічний показник становив 0,006 мг/гол.

При проведенні кореляційного аналізу одержаних експериментальних даних ми поставили такі завдання: охарактеризувати міру залежності між результативними ознаками та рівнем споживання птицею Селену за постійного значення інших чинників, а також визначити величини взаємозв'язку між ознаками, що входять в аналіз.

Результати кореляційного аналізу основного масиву експериментальних даних наведені у таблиці 3.

Аналіз даних таблиці 3 виявив сильні $(\mathrm{r}>0,75)$ по- зитивні кореляційні зв'язки між рівнем споживання Селену і перетравністю протеїну та клітковини, засвоєнням Азоту та Селену $(\mathrm{P}<0,05)$, вмістом в крові лейкоцитів ( $\mathrm{P}<0,001)$, гемоглобіну $(\mathrm{P}<0,05)$, загального білка та глутатіону (P < 0,05), вмістом у м'язовій тканині жиру $(\mathrm{P}<0,05)$ та Селену $(\mathrm{P}<0,05)$, харчовою цінністю грудних $(\mathrm{P}<0,01)$ і стегнових $(\mathrm{P}<0,05)$ м'язів, довжиною тонкого відділу кишечнику.

Позитивні, середньої сили коефіцієнти кореляції виявлено між рівнем споживання Селену і такими ознаками, як вміст в крові еритроцитів $(\mathrm{r}=0,72)$, маса напівпатраної тушки $(\mathrm{r}=0,70)$, вміст протеїну в стегнових м'язах $(\mathrm{r}=0,71)$, біологічна цінність грудних $\mathrm{i}$ стегнових м'язів ( $\mathrm{r}=0,71$ та $\mathrm{r}=0,55$ відповідно), жива маса птиці $(\mathrm{r}=0,70)$ та її збереженість $(\mathrm{r}=0,53)$. 
Таблиця 3

Взаємозв'язок між рівнем споживання курчатамибройлерами селену та змінними ознаками

\begin{tabular}{|c|c|}
\hline Показник & $\mathrm{r} \pm \mathrm{m}_{\mathrm{r}}$ \\
\hline Перетравність протеїну & $0,93 \pm 0,262$ \\
\hline Перетравність жиру & $0,39 \pm 0,651$ \\
\hline Перетравність клітковини & $0,78 \pm 0,446$ \\
\hline Перетравність БЕР & $-0,38 \pm 0,654$ \\
\hline Засвоєння Азоту & $0,81 \pm 0,419$ \\
\hline Засвоєння Селену & $0,97 \pm 0,184^{*}$ \\
\hline Вміст еритроцитів & $0,72 \pm 0,490$ \\
\hline Вміст лейкоцитів & $1,00 \pm 0,022^{* * *}$ \\
\hline Вміст гемоглобіну & $0,98 \pm 0,123^{*}$ \\
\hline Вміст загального білка & $0,85 \pm 0,369$ \\
\hline Вміст імуноглобулінів & $0,43 \pm 0,639$ \\
\hline Вміст загального глутатіону & $0,98 \pm 0,148^{*}$ \\
\hline Маса напівпатраної тушки & $0,70 \pm 0,506$ \\
\hline Маса патраної тушки & $0,46 \pm 0,628$ \\
\hline Маса їстівних частин тушки & $0,81 \pm 0,418$ \\
\hline Маса м’язів & $0,70 \pm 0,506$ \\
\hline \multicolumn{2}{|l|}{ Вміст у грудних м'язах: } \\
\hline протеїну & $0,01 \pm 0,707$ \\
\hline жиру & $0,94 \pm 0,232$ \\
\hline золи & $0,73 \pm 0,483$ \\
\hline Селену & $0,95 \pm 0,022^{*}$ \\
\hline Харчова цінність грудних м’язів & $1,00 \pm 0,064^{* *}$ \\
\hline Біологічна цінність грудних м'язів & $0,71 \pm 0,496$ \\
\hline \multicolumn{2}{|l|}{ Вміст у стегнових м'язах: } \\
\hline протеїну & $0,56 \pm 0,587$ \\
\hline жиру & $0,96 \pm 0,197^{*}$ \\
\hline золи & $0,93 \pm 0,260$ \\
\hline Селену & $0,93 \pm 0,252$ \\
\hline Харчова цінність стегнових м’язів & $0,97 \pm 0,158^{*}$ \\
\hline Біологічна цінність стегнових м'язів & $0,55 \pm 0,592$ \\
\hline Довжина тонкого відділу кишечнику & $0,84 \pm 0,385$ \\
\hline Жива маса & $0,70 \pm 0,507$ \\
\hline Збереженість & $0,53 \pm 0,600$ \\
\hline
\end{tabular}

Існує слабкий, але позитивний зв'язок $(0,25<\mathrm{r}<$
0,50) між рівнем споживання птицею Селену та перетравністю жиру, вмістом імуноглобулінів у сироватці крові, масою патраної тушки.

Крім того, встановлений зворотній, слабкої сили статистично невірогідний зв'язок $(\mathrm{r}=-0,38)$ між рівнем споживання курчатами-бройлерами Селену i перетравністю ними безазотистих екстрактивних речовин корму.

Обчислення коефіцієнтів кореляції також дозволило встановити, що між інтер'єрними та господарсько корисними ознаками, що входять в аналіз, мають місце різні рівні й напрями взаємозв'язку, які можуть змінюватися залежно від вмісту Селену в комбікормах для курчат-бройлерів (табл. 4).

Результати досліджень показують, що збагачення комбікормів для курчат-бройлерів Селеном помітно вплинуло на рівень обмінних процесів у їхньому організмі, що позитивно позначилося на продуктивних якостях молодняку. Свідченням цього $\epsilon$ сильні (r > 0,75) кореляційні зв'язки між живою масою молодняку та перетравністю ним протеїну, жиру та клітковини корму. Останні своєю чергою тісно взаємопов'язані 3 довжиною тонкого відділу кишечнику ( $\mathrm{r}=0,93 ; \mathrm{r}=0,75$ та $\mathrm{r}=1,00$ при $\mathrm{P}<0,01 \mathrm{r}=0,96$ при $\mathrm{P}<0,05$ відповідно).

Відомо, що жива маса птиці та рівень засвоєння біогенних елементів певною мірою залежить від розвитку органів травлення. Даний висновок яскраво підтверджується одержаною кореляцією між лінійними розмірами тонкого відділу кишечнику та живою масою молодняку ( $\mathrm{r}=0,98$ при $\mathrm{P}<0,05)$, а також засвоєння ним Азоту $(\mathrm{r}=0,96$ при $\mathrm{P}<0,05)$ та Селену $(\mathrm{r}=0,88)$.

Крім того, у курчат-бройлерів установлені численні сильні $(\mathrm{r}>0,75)$ та середньої сили $(0,75>\mathrm{r}>0,50)$ позитивні кореляційні зв'язки між фізіолого-біохімічними показниками крові та живою масою молодняку, з одного боку, та його збереженістю - з іншого.

\section{Таблиця 4}

Взаємозв’язки між досліджуваними показниками у курчат-бройлерів за дії Селену, $\left(\mathrm{r} \pm \mathrm{m}_{\mathrm{r}}\right)$

\begin{tabular}{lccc}
\hline \multicolumn{1}{c}{ Показник } & Жива маса & Збереженість & $\begin{array}{c}\text { Довжина тонкого відділу } \\
\text { кишечнику }\end{array}$ \\
\hline Жива маса & - & - & $0,98 \pm 0,157^{*}$ \\
Перетравність протеїну & $0,84 \pm 0,387$ & - & $0,93 \pm 0,256$ \\
Перетравність жиру & $0,80 \pm 0,427$ & $0,75 \pm 0,467$ \\
Перетравність клітковини & $0,98 \pm 0,134^{*}$ & - & $1,00 \pm 0,063^{* *}$ \\
Перетравність БЕР & $0,40 \pm 0,648$ & - & $0,21 \pm 0,691$ \\
Засвоєння Азоту & $0,91 \pm 0,292$ & - & $0,96 \pm 0,208^{*}$ \\
Засвоєння Селену & $0,76 \pm 0,462$ & - & - \\
Вміст еритроцитів & $0,79 \pm 0,429$ & $0,95 \pm 0,215^{*}$ & - \\
Вміст лейкоцитів & $0,65 \pm 0,535$ & - \\
Вміст гемоглобіну & $0,79 \pm 0,431$ & $0,50 \pm 0,610$ & - \\
Вміст загального білка & $0,91 \pm 0,288$ & $0,65 \pm 0,539$ & - \\
Вміст імуноглобулінів & $0,75 \pm 0,465$ & $0,99 \pm 0,558$ & - \\
Вміст загального глутатіону & $0,74 \pm 0,473$ & - \\
Маса напівпатраної тушки & $1,00 \pm 0,029^{* * *}$ & $0,69 \pm 0,515$ & - \\
Маса патраної тушки & $0,96 \pm 0,187^{*}$ & - & - \\
Маса істівних частин тушки & $0,96 \pm 0,188^{*}$ & - & - \\
Маса м'язів & $0,91 \pm 0,294$ & - & - \\
\hline Примітка. Вірогідність різниці: ${ }^{*}-\mathrm{P}<0,05 ;{ }^{* *}-\mathrm{P}<0,01 ;{ }^{* * *}-\mathrm{P}<0,001$ & &
\end{tabular}


Не можна не підкреслити і той факт, що існує сильна ( $\mathrm{r}=$ від 0,91 до 1,00$)$ здебільшого статистично вірогідна кореляція між живою масою курчатбройлерів у 42-денному віці та їхньою м'ясною продуктивністю, зокрема, масою напівпатраної та патраної тушки ( $>0,001$ та $\mathrm{P}<0,05$ відповідно), масою їстівних частин тушки $(\mathrm{P}<0,05)$ та масою м'язів.
Нами на основі даних кореляційного аналізу запропоновано схему прямого і опосередкованого впливу селену на обмінні процеси в організмі курчатбройлерів та їхні продуктивні якості, які з'єднані між собою за допомогою ліній, що відповідають статистично значущому зв’язку відповідних ознак (рис. 1).

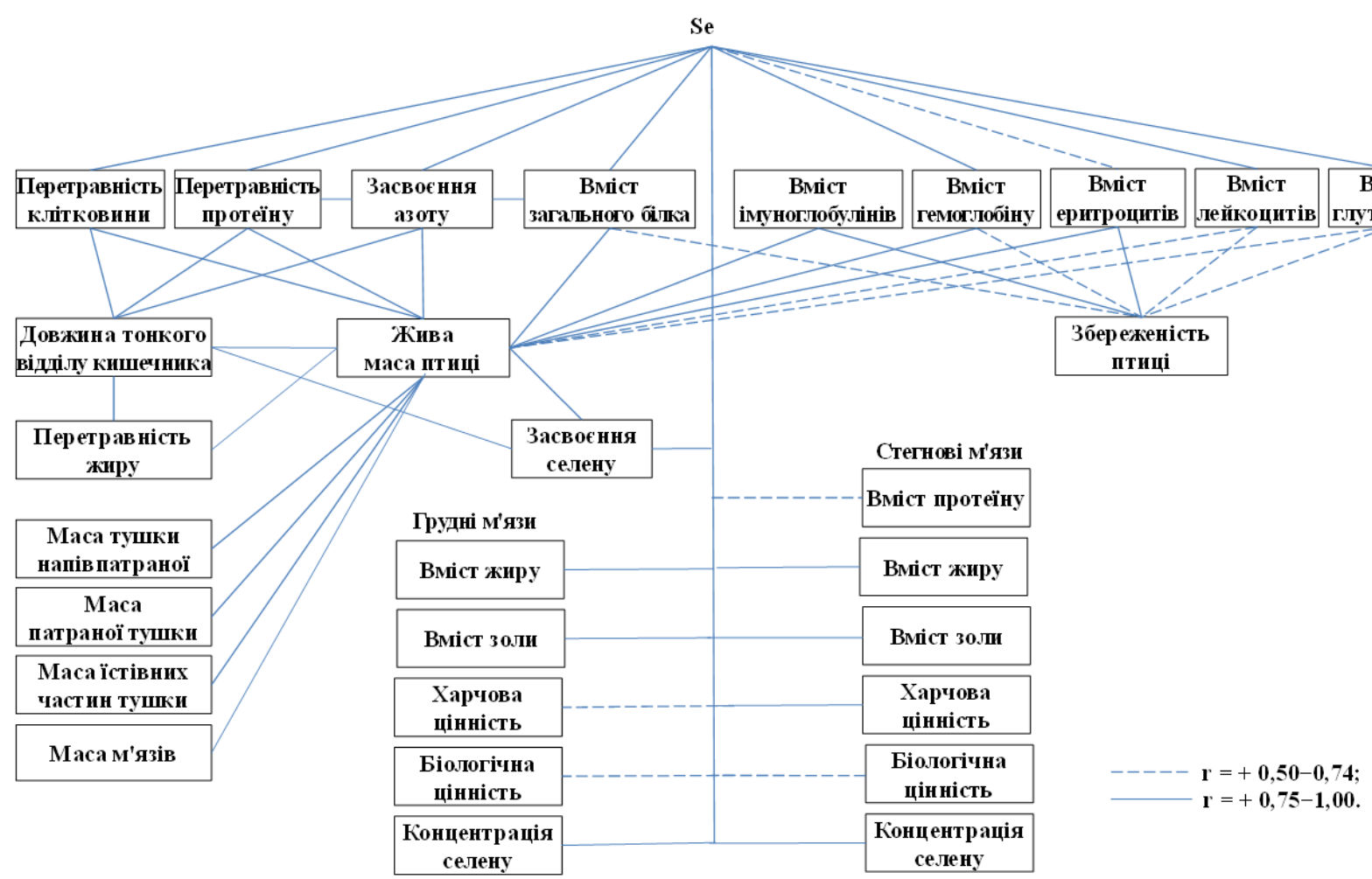

Рис. 1. Схема модулюючого впливу Селену на організм курчат-бройлерів

\section{Висновки}

На підставі аналізу результатів експериментальних досліджень обгрунтована доцільність використання Селену як мінеральної добавки в годівлі курчатбройлерів. Встановлено, що введення Селену до складу комбікормів для курчат-бройлерів змінює спрямованість фізіолого-біохімічних процесів в організмі, що позитивно впливає на ріст молодняку, його життєздатність, перетравність та використання поживних i мінеральних речовин корму, сприяє поліпшенню якості продукції та підвищенню ефективності ведення м'ясного птахівництва.

Визначено характер та ступінь кореляційних взаємозв'язків між рівнем споживання птицею Селену та кількісними та якісними показниками іiі продуктивності. Запропоновано схему моделюючого впливу Селену на організм курчат-бройлерів.

Результати проведених досліджень стали певним внеском у розвиток наукової концепції раціонального використання Селену в годівлі сільськогосподарської птиці.

\section{References}

Bratyshko, N. I., Gorobec', A. I., \& Prytulenko, O. V. (2005). Rekomendacii' z normuvannja godivli sil's'kogospodars'koi' ptyci. Birky: Instytut ptahivnyctva UAAN (in Ukrainian).

CFIA (2018). Consultation Summary on Maximum Nutrient Values in Poultry (Chicken and Turkey).

Cobb 500 (2018). Broiler performance nutrition supplement. Cobb-Vantress.coom.

DSTU ISO 1442:2005 (2008). M jaso ta m’jasni produkty. Metod vyznachennja vmistu vologi (kontrol'nyi metod) (ISO 1442:1997, IDT). [Chynnyj vid 2008-03-01]. Kyi’v. Derzhstandart Ukrai'ny. (Nacional'nyj standart Ukrai'ny) (in Ukrainian).

DSTU ISO 1443:2005 (2008). M jaso ta m jasni produkty. Metod vyznachennja zagal'nogo vmistu zhyru (ISO 1443:1973, IDT). [Chynnyj vid 2008-0301]. Kyi'v, Derzhspozhyvstandart Ukrai'ny. (Nacional'nyj standart Ukrai'ny) (in Ukrainian).

DSTU ISO 5983-1:2014 (2015). Korm dlja tvaryn. Vyznachannja vmistu azotu ta obchyslennja vmistu syrogo protei'nu. Chastyna 1. Metod K'jel'dalja (ISO 5983-1:2005, IDT). [Chynnyj vid 2015-07-01]. Kyi’v. Derzhspozhyvstandart Ukrai'ny. (Nacional'nyj standart Ukrai'ny) (in Ukrainian). 
DSTU ISO 5984:2004 (2006). Kormy dlja tvaryn. Vyznachennja vmistu syroi' zoly (ISO 5984:2002, IDT). [Chynnyj vid 2006-01-01]. Kyi'v. Derzhspozhyvstandart Ukrai'ny. (Nacional'nyj standart Ukrai'ny) (in Ukrainian).

DSTU ISO 6492:2003 (2005). Kormy dlja tvaryn. Vyznachennja vmistu zhyru (ISO 6492:1999, IDT).[Chynnyj vid 2005-07-01]. Kyi’v. Derzhspozhyvstandart Ukrai'ny. (Nacional'nyj standart Ukrai'ny) (in Ukrainian).

DSTU ISO 6496:2005 (2006). Korm dlja tvaryn. Vyznachennja vmistu vology ta inshyh letkyh rechovyn (ISO 6496:1999, IDT). [Chynnyj vid 200607-01]. Kyi'v. Derzhspozhyvstandart Ukrai'ny. (Nacional'nyj standart Ukrai'ny) (in Ukrainian).

DSTU ISO 6865:2004 (2006). Kormy dlja tvaryn. Vyznachennja vmistu syroi' klitkovyny metodom promizhnogo fil'truvannja (ISO 6865:2000, IDT). [Chynnyj vid 2006-04-01]. Kyi'v. Derzhspozhyvstandart Ukrai'ny. (Nacional'nyj standart Ukrai'ny) (in Ukrainian).

DSTU ISO 936:2008 (2008). M'jaso ta m'jasni produkty. Metod vyznachennja masovoi chastky zagal'noi zoly (ISO 936:1998, IDT). [Chynnyj vid 2008-09-01]. Kyi'v. Derzhspozhyvstandart. (Nacional'nyj standart Ukrai'ny) Ukrainy (in Ukrainian).

DSTU ISO 937:2005 (2007). M'jaso ta m'jasni produkty. Vyznachennja vmistu azotu (kontrol'nyi metod) (ISO 937-1978, IDT). [Chynnyj vid 2007-07-01]. Kyi'v. Derzhspozhyvstandart Ukrai'ny. (Nacional'nyj standart Ukrai'ny) (in Ukrainian).

Ejdrygevych, E. V., \& Raevskaja, V. V. (1966). Ynter'er sel'skohozjajstvennyh zhyvotnyh. Moskva. Kolos (in Russian).

Ermachenko, L. A. (1997). Atomno-absorbcionnyj analiz v sanitarno-gigienicheskih issledovanijah: metodicheskoe posobie. Moskva. Chuvashija (in Russian).

Fisinin, V.I. (2005). Selen v kormlenii pticy. Sergiev Posad: VNITIP (in Russian).

Górniak, W., Cholewinska, P., \& Konkol, D. (2018). Feed additives produced on the basis of organic forms of micronutrients as a means of biofortification of food of animal origin. Journal of Chemistry, 2018, 1-8. doi: 10.1155/2018/8084127.

Graupner, A., Eide, D.M., Instanes, C., Andersen, J.M., Brede, D.A., Dertinger, S.D., Lind, O.C., BrandtKjelsen, A., Bjerke, H., Salbu, B.,Oughton, D., Brunborg, G.,_\& Olsen, A. K. (2016). Gamma radiation at a human relevant low dose rate is genotoxic in mice. Scientific Reports, 6, 32977. doi: $10.1038 /$ srep32977.

Holak, W. (1980). Analysis of foods for lead, cadmium, copper, zinc, arsenic, and selenium, using closed system sample digestion: collaborative study. Association of Official Analytical Chemists, 63(3), 485-495. URL: https://pubmed.ncbi.nlm.nih.gov/7430035.

Huang, Z., Rose, A. H., \& Hoffmann, P. R. (2012). the role of selenium in inflammation and immunity: from molecular mechanisms to therapeutic opportunities. Antioxid Redox Signaling, 16(7), 705-743. doi: 10.1089/ars.2011.4145.
Kuršvietienè, L., Mongirdienė, A., Bernatonienė, J., Šulinskienè, J., \& Stanevičienè, I. (2020).Selenium anticancer properties and impact on cellular redox status. Antioxidants (Basel), 9(1), 80. doi: 10.3390/antiox9010080.

Levchenko, V. I., Novozhyc'ka, Ju. M., Sahnjuk, V. V. Tyshkivs'kyj, M. Ja., Golovaha, V. I., Moskalenko, V. P., Vovkotrub, N. V., Rozumnjuk, A. V., Golub, O. Ju., Tyshkivs'ka, N. V., Slivins'ka, L. G., Fasolja, V. P., \& Zhyla, I. A. (2004). Biohimichni metody doslidzhennja krovi tvaryn: metodychni rekomendacii' dlja likariv himiko-toksykologichnyh viddiliv derzhavnyh laboratorij veterynarnoi' medycyny Ukrai'ny, sluhachiv fakul'tetiv pidvyshhennja kvalifikacii' ta studentiv fakul'tetu veterynarnoi' medycyny. Kyi'v (in Ukrainian).

Maslieva, O. I. (1967). Metodika provedenija opytov i tehnika raschetov perevarimosti kormov i balansa pitatel'nyh veshhestv $\mathrm{v}$ organizme pticy. V knige : Metodiki nauchnyh issledovanij po kormleniju sel'skohozjajstvennoj pticy. Moskva. VYESH (in Russian).

Mikitjuk, P. V., Bukalova, N. V., Dzhmil', V. I., Hic'ka, O. A., Dzhmil', O. M., Sljusarenko, S. V., \& Utechenko, M. V. (2004). Metodychni vkazivky (mikrometod) shhodo vykorystannja infuzorii Tetrahimena piriformis dlja toksyko-biologichnoi ocinky sil's'kogospodars'kyh produktiv ta vody. Bila Cerkva (in Ukrainian).

Mughal, M. J., Peng, X., Kamboh, A. A., Zhou, Y., \& Fang, J. (2017). Aflatoxin $B_{1}$ induced systemic toxicity in poultry and rescue effects of selenium and zinc. Biological Trace Element Research, 178, 292 300. doi: 10.1007/s12011-016-0923-9.

Navidshad, B., Mohammadrezaei, M., Zarei, M., Valizadeh, R., Karamati, S., Rezaei, F., Jabbari, S., Kachoei, R., \& Esmaeilinasab, P. (2019). The new progresses in trace mineral requirements of broilers, a review. Iranian Journal of Applied Animal Science, 9(1), 9-16. URL: http://ijas.iaurasht.ac.ir/article_663518.html.

Nys, Y., Schlegel, P., Durosoy, S., Jondreville, C., \& Narcy, A. (2018). Adapting trace mineral nutrition of birds for optimising the environment and poultry product quality. World's Poultry Science Journal, 74(2), 225-238. doi: 10.1017/S0043933918000016.

Ponomarenko, Ju. (2007). Selen i jod v racionah brojlerov. Pticevodstvo, 4, 38-39 (in Russian).

Provatorov, G. V., \& Provatorova, V. O. (2015). Godivlja sil's'kogospodars'kyh tvaryn: pidruchnyk. Sumy, Universytets'ka knyga (in Ukrainian).

Ross Broiler (2019). Nutrition Specifications. Aviagen, Huntsville.

Rostagno, H. S., Albino, L. F. T., Donzele, J. L., Gomes, P. C., de Oliveira, R. F., Lopes, D. C., Ferreira, A. S., Barreto, S. L. T, \& Euclides, R. F. (2011). Brazilian tables for poultry and swine : composition of feedstuffs and nutritionalrequirements. 3 ed. Santiago Rostagno.Viçosa, MG: UFV, DZO.

Shakeri, M., Oskoueian, E., Le, H. H., \& Shakeri, M. (2020). Strategies to combat heat stress in broiler chickens: unveiling the roles of selenium, vitamin $\mathrm{E}$ 
and vitamin C. Veterinary sciences, 7(2), 71. doi: 10.3390/vetsci7020071.

Shojadoost, B., Kulkarni, R. R., Yitbarek, A., Laursen, A., Taha-Abdelaziz, K., Negash Alkie, T., Barjesteh, N., Quinteiro-Filho, W. M., Smith, T. K., \& Sharif, S. (2019). Dietary selenium supplementation enhances antiviral immunity in chickens challenged with low pathogenic avian influenza virus subtype H9N2. Vet Immunol Immunopathol. 207, 62-68. doi: 10.1016/j.vetimm.2018.12.002.

Sobolev, O. I., Lisohurska, D. V., Pyvovar, P. V., Topolnytskyi, P. P., Gutyj, B. V., Sobolieva, S. V., Borshch, O. O., Liskovich, V. A., Verkholiuk, M. M., Petryszak, O. Y., Kuliaba, O. V., Golodiuk, I. P., Naumjuk, O. S., Petryszak, R. A., \& Dutka, H. I. (2021). Modeling the effect of different dose of selenium additives in compound feed on the efficiency of broiler chicken growth. Ukrainian Journal of Ecology, 11 (2), 292-299. doi: 10.15421/2021_113.

Sobolev, O., Gutyj, B., Petryshak, R., Pivtorak, J,. Kovalskyi, Y., Naumyuk, A,. Petryshak, O., Semchuk, I., Mateusz, V., Shcherbatyy, A., \& Semeniv, B. (2018). Biological role of selenium in the organism of animals and humans. Ukrainian Journal of Ecology, 8(1), 654-665. doi: 10.15421/2017_263.

Surai, P. F., Kochish, I. I., Fisinin, V. I., \& Velichko, O. A. (2018). Selenium in Poultry Nutrition: from Sodium Selenite to Organic Selenium Sources The journal of poultry science, 55(2), 79-93. doi: 10.2141/jpsa.0170132.

Zoidis, E., Seremelis, I., Kontopoulos, N., \& Danezis, G. P. (2018). Selenium-dependent antioxidant enzymes: actions and properties of selenoproteins. Antioxidants, 7(5), 66. doi: 10.3390/antiox7050066. 